\title{
Hormonal regulation of apoptosis in rabbit granulosa cells in vitro: evaluation by flow cytometric detection of plasma membrane phosphatidylserine externalization
}

\author{
G. Maillet, E. Bréard, A. Benhaïm, P. Leymarie and C. Féral \\ Laboratoire de Biochimie, UPRES EA 2608, CHU Côte de Nacre, Université de Caen, 14032 \\ Caen Cedex, France
}

\begin{abstract}
Annexin $\mathrm{V}$ and propidium iodide bivariate analysis and the TUNEL method were used to quantify hormonal regulation of apoptosis in rabbit granulosa cells from preovulatory follicles in vitro. The aim of this study was to analyse comparatively the effects of gonadotrophins and their second messenger in the regulation of granulosa cell apoptosis in (i) cultured isolated granulosa cells and (ii) granulosa cells scraped from cultured follicles. The results showed that increasing doses of FSH had no effect on apoptosis of cultured isolated cells but caused a decrease in the number of apoptotic granulosa cells from preovulatory follicles cultured in serum-free conditions. Unlike FSH, addition of hCG did not modify apoptosis of
\end{abstract}

granulosa cells significantly. In contrast, dibutyryl cAMP had an apoptotic effect in the two cellular models in the presence of serum. Moreover, a biphasic effect of dibutyryl cAMP in isolated granulosa cells was observed with an increase in the incorporation of $\left[{ }^{3} \mathrm{H}\right]$ thymidine into DNA at the lowest dose and an increase in apoptotic cell death at the highest dose. It was concluded that, in rabbits: (i) FSH requires follicle integrity to exert its anti-apoptotic effect in granulosa cells; (ii) dibutyryl cAMP induces a dose-dependent apoptotic effect in granulosa cells cultured alone or obtained from cultured preovulatory follicles; and (iii) cAMP signals induce opposite effects on growth and apoptosis in granulosa cells.

\section{Introduction}

Apoptotic cell death of granulosa cells is the underlying event associated with initiation of follicular atresia (Hughes and Gorospe, 1991; Tilly et al., 1991, 1992). Gonadotrophins play a major role in the development of ovarian follicles and, thus, FSH and LH are likely to be survival factors in follicular apoptosis. In most studies, the ability of gonadotrophins to suppress apoptosis has been tested in vivo (Billig et al., 1994) or in vitro in an intact follicle culture system (Chun et al., 1994, 1996; Kaipia et al., 1996). When tested in isolated granulosa cells, FSH was ineffective in rats (Aharoni et al., 1995), whereas it attenuated apoptosis in pigs (Guthrie et al., 1998) and cows (Yang and Rajamahendran, 2000; Hu et al., 2001).

The effects of gonadotrophins are exerted via an increase in intracellular cAMP. The effect of the cAMP analogue, dibutyryl cAMP (dbcAMP), on follicular apoptosis is controversial. Indeed, dbcAMP was described as apoptotic in isolated granulosa cells from preovulatory rat follicles (Aharoni et al., 1995) but as a survival factor in cultured early antral rat follicles (Chun et al., 1996).

No study has been performed using both isolated granulosa cells and cultured follicles to study the role of

Email: maillet.geraldine@caramail.com paracrine interactions between follicular cells in the action of gonadotrophins against apoptosis, as was suggested by Hsueh et al. (1996).

Apoptosis is characterized by internucleosomal DNA cleavage in association with morphological changes including membrane blebbing, nuclear condensation or fragmentation and formation of apoptotic bodies. In addition, cells induced to undergo apoptosis show a loss of phospholipid asymmetry in the plasma membrane, which results in the exposure of phosphatidylserine on the outer leaflet. This phosphatidylserine exposure can be used to detect apoptosis in vital, non-fixed cells by allowing fluorescein isothiocyanate (FITC)-labelled annexin V to bind to phosphatidylserine.

On the basis of the above considerations, the aim of the present study was to determine whether gonadotrophins can modulate apoptosis in isolated rabbit granulosa cells or in granulosa cells obtained from cultured preovulatory rabbit follicles. The role of dbcAMP in the regulation of apoptotic death of granulosa cells was also studied in parallel with $\left[{ }^{3} \mathrm{H}\right]$ thymidine incorporation and steroid production. Apoptosis was evaluated in granulosa cells using the propidium iodide and annexin $\mathrm{V}$ bivariate analysis proposed by Vermes et al. (1995). This method was used for the detection of the early stage of apoptosis and, in contrast to the TUNEL method, allowed rapid analysis of data. 


\section{Materials and Methods}

\section{Animals and treatments}

HY female white rabbits, aged 10-12 weeks (Elevage Gastebled, Hottot Les Bagues), were housed individually for about 2 weeks on a $14 \mathrm{~h}$ light (from 06:00 h to 20:00 h) and $10 \mathrm{~h}$ dark schedule with standard rabbit food and water available ad libitum. Animals were bred under standard conditions according to the instructions of Ministère de I'Agriculture et de la Pêche-Service Santé Animale (France).

The development of numerous preovulatory follicles was induced in these rabbits by i.m. injection of 200 iu eCG (Chrono-Gest; Intervet, Paris) daily for 2 days. The animals were killed by intracardiac injection of $2 \mathrm{ml}$ of a narcotic (Embutramide T61; Distrivet, Paris) 4 days after the first injection of eCG.

The ovaries were excized and placed in minimum essential medium (MEM; Eurobio, Les Ulis) containing $20 \mathrm{mmol}^{\mathrm{H}}$ Hepes $\mathrm{I}^{-1}$ (Sigma, St Quentin Fallavier), $50 \mathrm{iu}$ penicillin $\mathrm{ml}^{-1}$ (Sigma), $50 \mu \mathrm{g}$ streptomycin $\mathrm{ml}^{-1}$ (Eurobio) and $0.1 \%(\mathrm{w} / \mathrm{v})$ BSA (Sigma). The follicles were dissected out (those containing clotted blood were discarded) and cleared of interstitial tissue under a stereomicroscope.

\section{Granulosa cell preparation and culture protocols}

Dispersed granulosa cells were obtained as described by Féral et al. (1995). In brief, follicles were cut in half in MEM-0.1\% (w/v) BSA containing 6.8 mmol EGTA $\mathrm{I}^{-1}$ (Sigma) and incubated for $10 \mathrm{~min}$. Released granulosa cells and follicles were centrifuged together at $300 \boldsymbol{g}$ for $10 \mathrm{~min}$ and resuspended in MEM-0.1\% (w/v) BSA containing

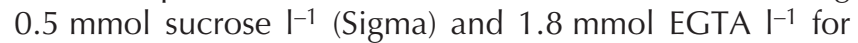
$5 \mathrm{~min}$ before centrifugation again at $300 \mathrm{~g}$ for $10 \mathrm{~min}$. Granulosa cells were gently scraped away from the theca with a microspatula under a dissecting microscope. The dispersed granulosa cells were pelleted by centrifugation at $300 \mathrm{~g}$ for $10 \mathrm{~min}$, subjected to mechanical dissociation, washed twice in MEM-0.1\% (w/v) BSA and resuspended in serum-free or serum-containing medium with or without gonadotrophins.

After $72 \mathrm{~h}$ of culture, the media were collected and stored at $-20^{\circ} \mathrm{C}$ until the steroid assays were performed and the cells were treated for apoptosis analysis.

\section{Follicle culture}

Preovulatory follicles were dissected from ovaries as described above. Six follicles per treatment group were placed in Falcon 24-well tissue culture plates containing 1 $\mathrm{ml}$ culture medium in the absence or presence of gonadotrophins with or without $5 \%$ fetal calf serum (FCS) and incubated for $72 \mathrm{~h}$. After culture, the follicles of each treatment group were washed in MEM-0.1\% (w/v) BSA and granulosa cells were obtained after treatment with EGTAsucrose and scraping as described above. The analysis of phosphatidylserine exposure was carried out in the same way as for cultured isolated granulosa cells.
Measurement of phosphatidylserine exposure of granulosa cells by flow cytometry

For analysis of phosphatidylserine exposure, $3 \times 10^{5}$ cells $\mathrm{ml}^{-1}$ were cultured in the presence or absence of experimental treatments in Falcon 24-well tissue culture plates for $72 \mathrm{~h}$. Adherent cells were washed twice with warm PBS without $\mathrm{Ca}^{2+}$ or $\mathrm{Mg}^{2+}$ and were treated for $5 \mathrm{~min}$ at $37^{\circ} \mathrm{C}$ with PBS containing $0.5 \mathrm{~g}$ trypsin $\mathrm{I}^{-1}$ and $0.2 \mathrm{~g}$ EDTA $I^{-1}$ (Eurobio). Trypsin activity was stopped by the addition of medium supplemented with $5 \%(\mathrm{v} / \mathrm{v})$ FCS.

At the end of the culture period, apoptotic granulosa cells were quantified according to the manufacturer's instructions for annexin V-FITC kit (Boehringer-Ingelheim kit; supplied by Coger, Paris). After two washes with binding buffer, annexin V-FITC $\left(3 \mu \mathrm{g} \mathrm{ml}^{-1}\right)$ and propidium iodide $\left(400 \mathrm{ng} \mathrm{m}^{-1}\right)$ were added to the cell suspension $\left(3 \times 10^{5}\right.$ cells per $500 \mu \mathrm{l}$ ) and incubated for $10 \mathrm{~min}$ in the dark. Granulosa cells were analysed during the hour after incubation in a fluorescence-activated cell sorter (FACScalibur; Becton-Dickinson, Sunnyvale, CA) using a $15 \mathrm{~mW}$ argon laser emitting light at $488 \mathrm{~nm}$. The following settings were used for bicolour analysis: $475 \mathrm{~V}$ on photomultiplier tubes for both FL1 (FITC) and FL2 (propidium iodide). Compensation for FL1-\%FL2 and FL2$\%$ FL1 was 1.0 and $32.5 \%$, respectively. Data analysis was performed with Cell Quest software (Becton Dickinson). Ten thousand cells were analysed in each treatment group. In each experiment, quadrants were fixed using the dot plot of granulosa cells cultured in serum-containing medium as shown (Fig. 1). The diagram of granulosa cells obtained from culture in the presence of serum was considered as a control. The incidence of apoptosis in the control is stated in each figure legend. The results of treatments with gonadotrophins and dbcAMP were expressed as an apoptotic cell percentage of the control.

\section{Measurement of DNA fragmentation by TUNEL method}

For the study of DNA fragmentation by terminal deoxynucleotide transferase-mediated dUTP-biotin nickend labelling (TUNEL) method, $2 \times 10^{5}$ cells $\mathrm{ml}^{-1}$ were grown onto a round coverslip placed in the bottom of each well of Falcon 24-well tissue culture plates. Cells were prepared according to the manufacturer's indications for the TdT-FragEL ${ }^{\text {TM }}$ kit (Amersham, Orsay).

In brief, at the end of culture, cells on coverslips were fixed with 3\% (w/v) paraformaldehyde (Merck, Fontenay sous Bois) for $30 \mathrm{~min}$ at room temperature, washed intensively with TBS and permeabilized for $5 \mathrm{~min}$ with proteinase $\mathrm{K}\left(20 \mu \mathrm{g} \mathrm{m}^{-1}\right)$ followed by washing with TBS. DNA fragmentation in cultured cells was assessed using the TdTFragEL ${ }^{T M}$ kit. Coverslips were counterstained with methyl green and mounted using DePeX mounting medium.

A negative control was obtained by omitting the terminal deoxynucleotidyl transferase (TdT) enzyme in the reaction mixture during the labelling step.

Cells with labelled nuclei and total cells were counted in 

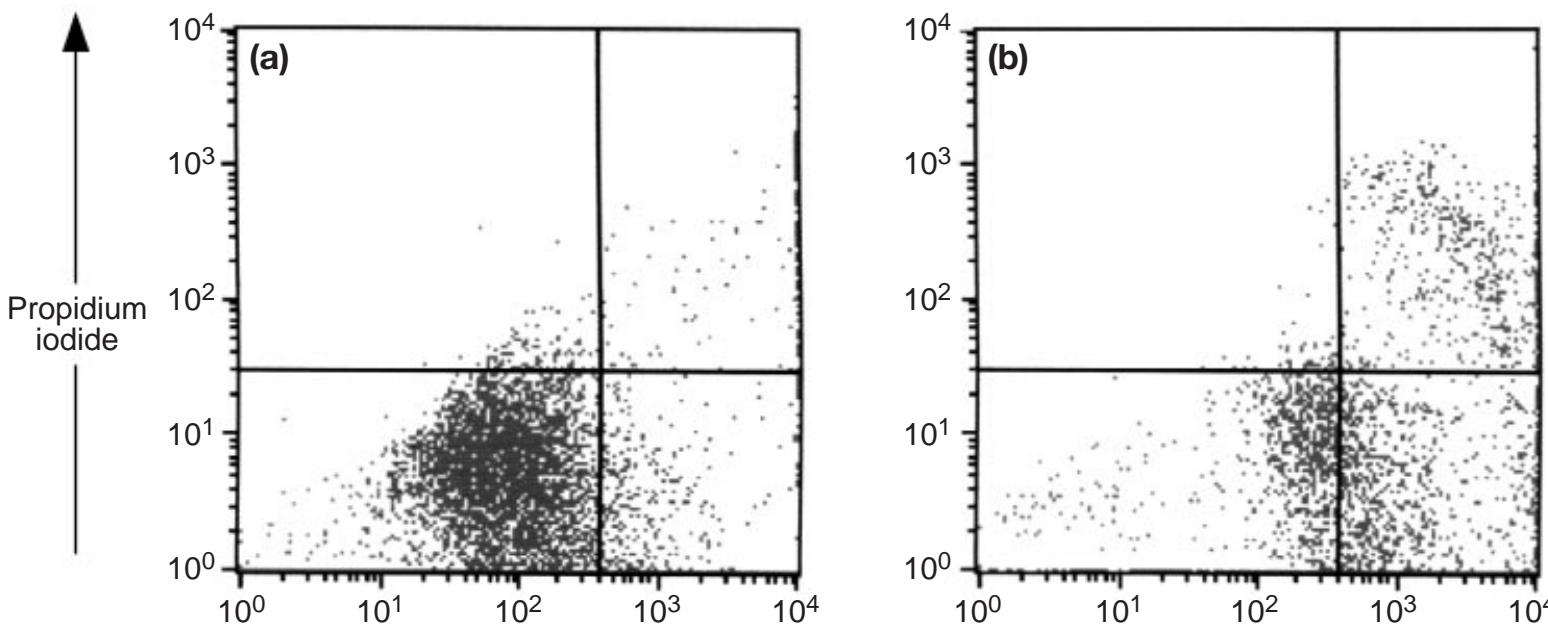

\section{Annexin V FITC}

Fig. 1. Dot plots of annexin $\mathrm{V}$ fluorescein isothiocyanate (FITC)-propidium iodide two-parameter flow cytometry of rabbit granulosa cells cultured (a) with fetal calf serum (FCS) (considered as control) and (b) in serum-free conditions. The lower left quadrant contains cells considered as healthy (annexin-/propidium iodide-). The lower right quadrant shows apoptotic cells (annexin+/propidium iodide-) and the upper quadrants represent necrotic and secondary necrotic cells (propidium iodide+). Fluorescence intensities are expressed in arbitrary units.

five random fields scoring 500-800 cells of each treated culture to quantify DNA fragmentation. The percentage of apoptotic nuclei was estimated independently by two people in three independent experiments. Data are expressed as mean \pm SEM.

\section{Measurement of $\left.{ }^{3} \mathrm{H}\right]$ thymidine incorporation into DNA}

Granulosa cells $\left(10^{5}\right.$ cells per $\left.500 \mu \mathrm{l}\right)$ were cultured for $72 \mathrm{~h}$ in Falcon 48-well tissue culture plates in serumcontaining medium and treated with increasing doses of dbcAMP (Sigma) during the last $48 \mathrm{~h} .1 \mu \mathrm{Ci}\left[{ }^{3} \mathrm{H}\right]$ thymidine $\mathrm{ml}^{-1}$ (25 Ci mmol${ }^{-1}$ ) (Amersham) was added to the culture medium for the final $24 \mathrm{~h}$. The amount of $\left[{ }^{3} \mathrm{H}\right]$ thymidine incorporated into DNA was determined as described by Benhaïm et al. (1995). The amount of $\left[{ }^{3} \mathrm{H}\right]$ thymidine incorporation into DNA was expressed in c.p.m. per $10^{5}$ cells.

\section{Progesterone and oestradiol production}

The concentrations of progesterone and oestradiol in culture media were measured by radioimmunoassay using specific antibodies (BioSys, Compiègne). Sensitivity was 3 pg per tube for oestradiol and $5 \mathrm{pg}$ per tube for progesterone.

\section{Statistical analysis}

Data regarding the production of steroids, the incorporation of $\left[{ }^{3} \mathrm{H}\right]$ thymidine and the percentage of apoptotic cells were expressed as mean \pm SEM of at least three experiments. In each experiment, the different treatments were performed on cells from two rabbits. Data regarding the percentage of apoptotic cells obtained with the TUNEL method and annexin $\mathrm{V}$ binding analysis needed an arcsin transformation to obtain a normal distribution. Differences between treatment groups (raw data for the production of steroids and the incorporation of $\left[{ }^{3} \mathrm{H}\right]$ thymidine or transformed data for the percentage of apoptotic cells) were assessed by a two-way ANOVA followed by Fisher's test and considered significant at $P<0.05$.

\section{Results}

\section{Apoptosis in cultured granulosa cells}

The study of variation in the number of apoptotic cells in cultured granulosa cells was performed at 24, 48 and $72 \mathrm{~h}$ in the presence or absence of $5 \%$ serum. The analysis of phosphatidylserine exposure showed that the percentage of apoptotic granulosa cells increased significantly in serum-free conditions compared with culture in the presence of serum at all the times tested (24-72 h of culture; Fig. 2). A time-dependent decrease in the percentage of apoptotic cells was observed. In each case, this decrease was significant at $72 \mathrm{~h}$ of culture compared with $24 \mathrm{~h}$ $(P<0.05)$ and, thus, further experiments were performed after $72 \mathrm{~h}$ of culture.

Granulosa cell apoptosis as shown by analysis of phosphatidylserine exposure was confirmed by the TUNEL method (Table 1). In the presence of serum for $72 \mathrm{~h}$, $29 \pm 3 \%$ of cells labelled for fragmented DNA; this percentage was increased 2.6-fold in serum-free conditions $(P<0.001)$. 


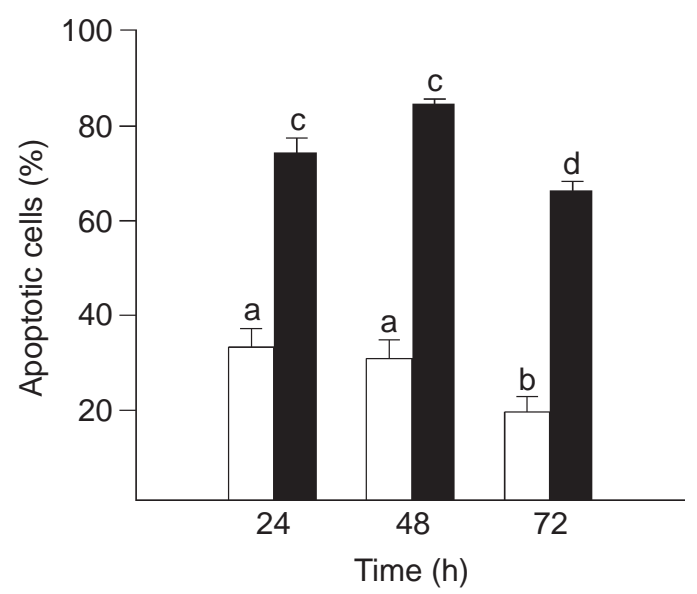

Fig. 2. Time-dependent effect of culture with ( $\square$ ) or without ( fetal calf serum (FCS) on percentage of apoptotic rabbit granulosa cells. Data are mean \pm SEM of three experiments performed in triplicate. ${ }^{a-d}$ Values with different superscripts are significantly different $(P<0.05)$.

\section{Effect of gonadotrophins on apoptosis in isolated cultured granulosa cells}

Isolated granulosa cells were cultured for $72 \mathrm{~h}$ in the presence or absence of serum. The effect of increasing

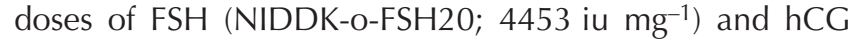
(LH activity) (Organon, Serifontaine) on apoptosis of granulosa cells was evaluated in each culture condition.

In the presence of serum, the addition of FSH at concentrations ranging from $5 \mathrm{ng} \mathrm{ml}^{-1}$ to $100 \mathrm{ng} \mathrm{ml}^{-1}$ did not affect the percentage of apoptotic granulosa cells significantly. The absence of serum in culture medium induced a 2.3 -fold increase in the percentage of apoptotic cells above control in serum conditions. In this serum-free condition, the percentage of apoptotic granulosa cells was not affected by treatment with increasing doses of FSH (Fig. 3a).

The addition of increasing doses of hCG ranging from

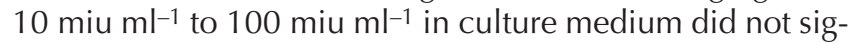
nificantly affect the percentage of apoptotic granulosa cells in either the presence or absence of serum (Fig. 4a).

Granulosa cells cultured in serum-containing medium responded to addition of gonadotrophins in terms of steroidogenesis. Addition of FSH $\left(100 \mathrm{ng} \mathrm{ml}^{-1}\right)$ and hCG (100 miu $\mathrm{ml}^{-1}$ ) increased progesterone production 20- and 14-fold, respectively (data not shown).

\section{Effect of gonadotrophins on apoptosis in granulosa cells from cultured preovulatory follicles}

Preovulatory follicles were cultured for $72 \mathrm{~h}$ in the presence or absence of serum with or without gonadotrophins to assess further the role of gonadotrophins in modulating granulosa cell apoptosis. Granulosa cells were scraped from these follicles and analysed for apoptosis.

In the presence of serum, addition of increasing doses of FSH did not significantly affect the percentage of apoptotic granulosa cells removed from cultured preovulatory follicles (Fig. 3b). The absence of serum in culture medium induced a two-fold increase in the percentage of apoptotic cells compared with the control in serum conditions when granulosa cells were removed from cultured preovulatory follicles. In this serum-free culture, addition of FSH induced a dose-dependent decrease in the percentage of apoptotic granulosa cells.

The treatment of cultured preovulatory follicles with increasing doses of hCG did not significantly affect the percentage of apoptotic granulosa cells in either serumcontaining medium or in serum-free conditions (Fig. 4b).

\section{Induction of apoptosis by increasing doses of dbcAMP in cultured granulosa cells}

Cells were cultured with or without serum in the presence of increasing concentrations $\left(0.1-5.0 \mathrm{mmol} \mathrm{I}^{-1}\right)$ of dbcAMP to test the effects of the gonadotrophin second messenger cAMP on granulosa cell apoptosis. When granulosa cells were cultured in the presence of serum, the percentage of apoptotic cells was increased by dbcAMP in a dose-dependent way: 5 mmol dbcAMP ${ }^{-1}$ induced a $70 \%$ increase in the number of apoptotic cells compared with the control (Fig. 5a). The absence of change in the percentage of propidium iodide-unlabelled cells (cells without a damaged membrane) with increasing doses of dbcAMP $(98 \pm 1 \%$

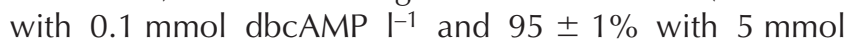
dbcAMP ${ }^{-1} ; n=3$ ) excluded a cytotoxic effect of high doses of dbcAMP. These results obtained with the annexin $V$ binding assay were confirmed by TUNEL analysis; treatment with dbcAMP induced a dose-dependent increase in the percentage of apoptotic cells compared with culture in the presence of serum only (Table 1).

The effects of dbcAMP on apoptosis in granulosa cells cultured in serum-containing media were compared with $\left[{ }^{3} \mathrm{H}\right]$ thymidine incorporation into DNA (Fig. 6). The incorporation of $\left[{ }^{3} \mathrm{H}\right]$ thymidine was increased by $130 \%$ at 0.1 mmol dbcAMP $\left.\right|^{-1}$ compared with the control $(P<0.001)$,

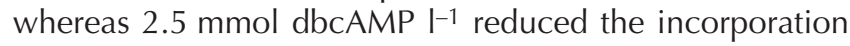
of $\left[{ }^{3} \mathrm{H}\right]$ thymidine by $30 \%(P<0.001)$.

Progesterone and oestradiol were also stimulated by dbcAMP in a dose-dependent manner (Fig. 7).

In the absence of serum, increasing doses of dbcAMP had no significant effect on the percentage of apoptotic granulosa cells, except for the high dose of 5 mmol dbcAMP $\mathrm{I}^{-1}$ (Fig. 5a).

\section{Effect of increasing doses of dbcAMP on apoptosis in granulosa cells from cultured preovulatory follicles}

As for gonadotrophins, the effect of dbcAMP on the percentage of apoptotic granulosa cells was tested on preovulatory follicles cultured in the presence or absence of serum. When granulosa cells were scraped from follicles cultured in the presence of serum (Fig. 5b), dbcAMP induced an increase in the percentage of apoptotic granulosa cells in a dose-dependent way, reaching a three-fold increase at 5 mmol dbcAMP I-1. 
Table 1. Analysis of the effects of fetal calf serum (FCS) deprivation and increasing doses of dibutyryl cAMP (dbcAMP) on rabbit granulosa cell apoptosis detected by the TUNEL method

\begin{tabular}{lccccc}
\hline & \multicolumn{4}{c}{$+\mathrm{FCS}(+\operatorname{dbcAMP}(\mathrm{mmol} \mathrm{l-1}))$} & - FCS \\
\cline { 2 - 4 } & 0 & 0.1 & 2.5 & 5.0 & \\
\hline Percentage of apoptotic nuclei $(n=3)^{\mathrm{a}}$ & $29 \pm 3$ & $32 \pm 4$ & $47 \pm 3^{* *}$ & $55 \pm 3^{* * *}$ & $77 \pm 7^{* * *}$ \\
\hline
\end{tabular}

aData are expressed as the mean percentage \pm SEM obtained by scoring about 500-800 total cell nuclei in five different fields for each treatment.

Values are mean \pm SEM of three experiments.

${ }^{* *} P<0.01$ and ${ }^{* * *} P<0.001$ compared with serum only value (+ FCS).
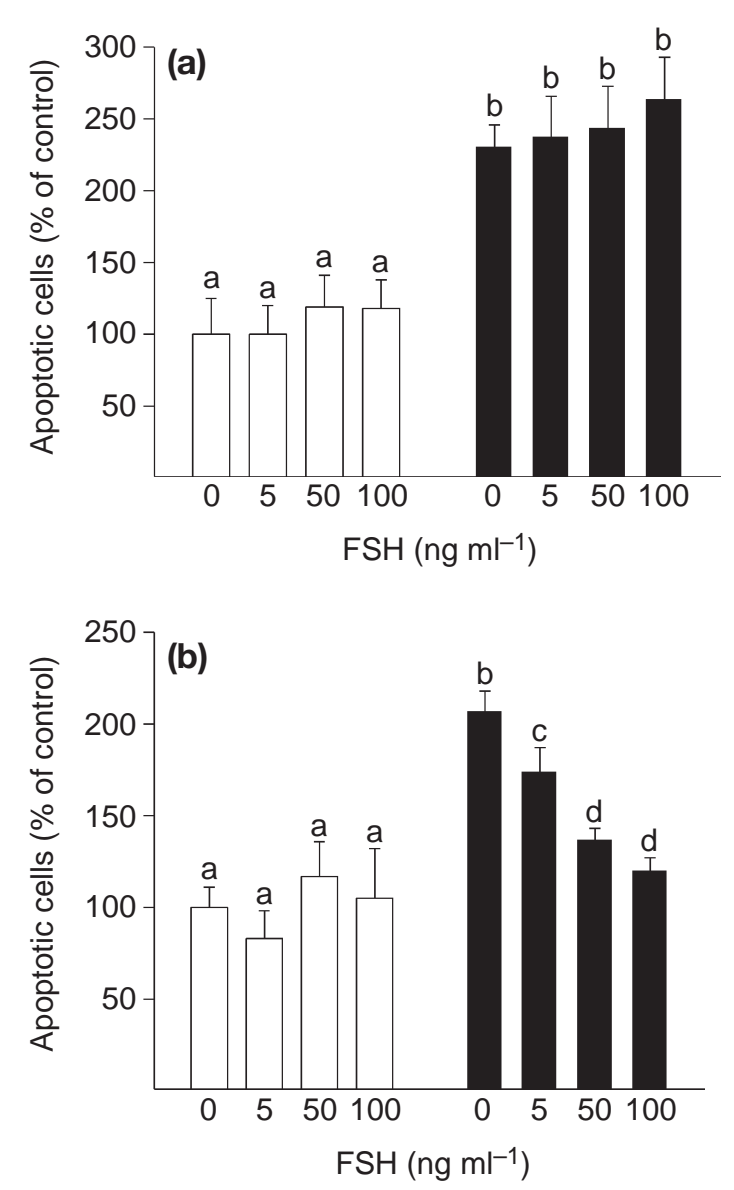

Fig. 3. Effect of increasing doses of FSH on apoptosis in rabbit (a) isolated granulosa cells and (b) granulosa cells scraped from preovulatory follicles, both cultured for $72 \mathrm{~h}$ in the presence $(\square)$ or absence $(\boldsymbol{\square})$ of fetal calf serum (FCS). (a) Data are mean \pm SEM of three experiments performed in triplicate. (b) Data are mean \pm SEM of five experiments. In (a), control $=23.6 \pm 5.8 \%$ apoptotic cells and in (b), control $=6.7 \pm 0.9 \%$ apoptotic cells. ${ }^{a-d}$ Values in a panel with different superscripts are significantly different $(P<0.05)$.

When follicles were cultured in the absence of serum, a three-fold increase in the percentage of apoptotic granulosa cells was observed. This percentage was not changed significantly by treatment with increasing concentrations of dbcAMP.
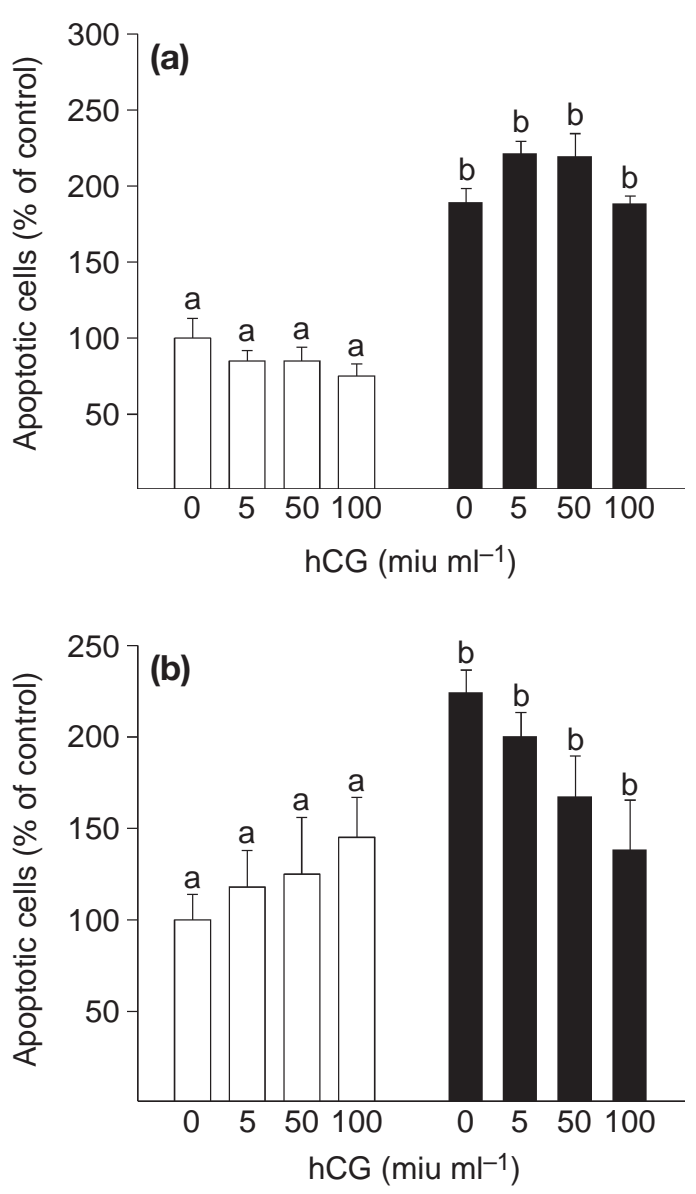

Fig. 4. Effect of increasing doses of hCG on apoptosis in rabbit (a) isolated granulosa cells and (b) granulosa cells scraped from preovulatory follicles, both cultured for $72 \mathrm{~h}$ in the presence $(\square)$ or absence (ם) of fetal calf serum (FCS). (a) Data are mean \pm SEM of three experiments performed in triplicate. (b) Data are mean \pm SEM of five experiments. In (a), control $=20.4 \pm 4.1 \%$ apoptotic cells and in (b), control $=6.1 \pm 1.0 \%$ apoptotic cells. ${ }^{\text {ab }}$ Values in a panel with different superscripts are significantly different $(P<0.05)$.

\section{Discussion}

In this study, the effect of gonadotrophins on the degree of apoptosis in isolated rabbit granulosa cells and in granulosa cells obtained from cultured preovulatory rabbit follicles in 

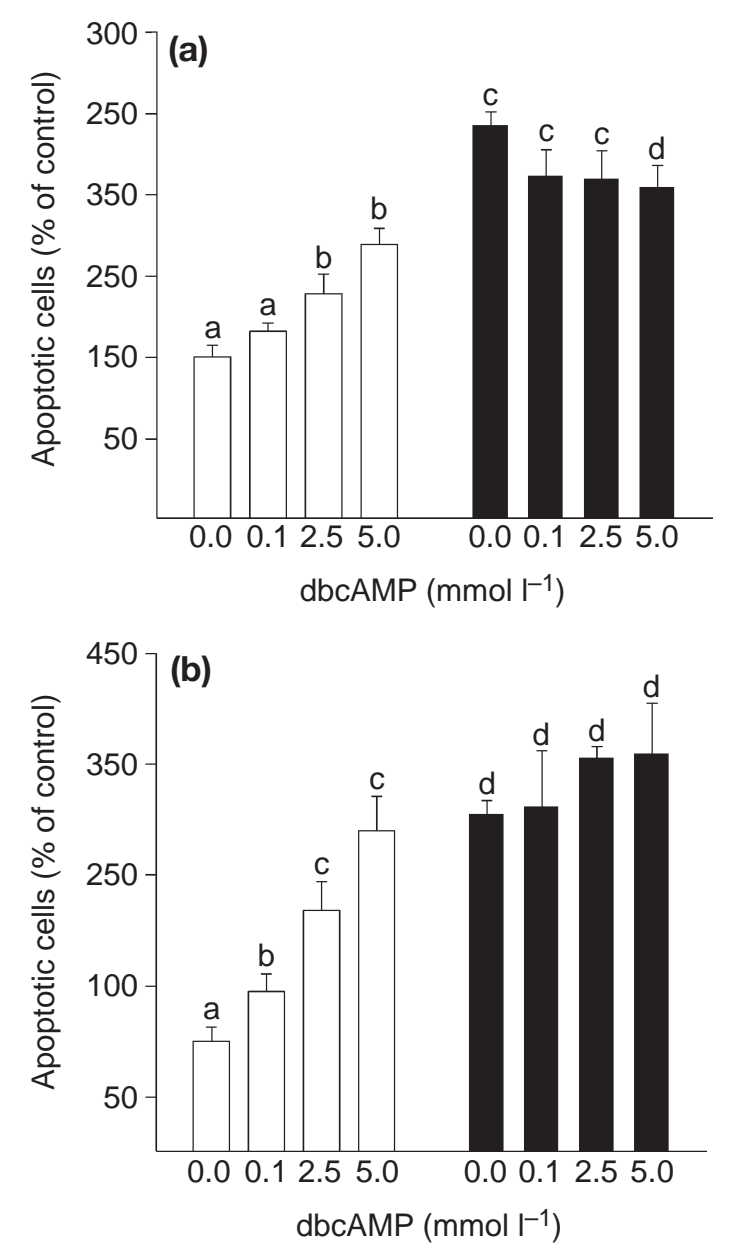

Fig. 5. Effect of increasing doses of dibutyryl cAMP (dbcAMP) on apoptosis in rabbit (a) isolated granulosa cells and (b) granulosa cells scraped from preovulatory follicles, both cultured for $72 \mathrm{~h}$ in the presence $(\square)$ or absence ( $\square$ ) of fetal calf serum (FCS). (a) Data are mean \pm SEM of three experiments performed in duplicate. (b) Data are mean \pm SEM of five experiments. In (a), control $=24 \pm 2 \%$ apoptotic cells and in (b), control $=3.2 \pm 0.4 \%$ apoptotic cells. ${ }^{a-d}$ Values with different superscripts are significantly different $(P<0.05)$.

the presence or absence of serum was compared in the same experiment. Although the increase in the percentage of apoptotic granulosa cells caused by serum deprivation was equivalent in isolated cells and in cells from cultured follicles (about 2.3-fold compared with serum conditions), the incidence of apoptosis in serum-containing medium was greater when granulosa cells were cultured alone than when they were obtained from cultured preovulatory follicles (23\% versus 6\% apoptotic granulosa cells, respectively). This finding indicates that there may be a protective effect of preovulatory follicle integrity on apoptosis of granulosa cells. Indeed, cell-cell adhesion sites and particularly cell adhesion molecules have been implicated in survival of human granulosa cells (Makrigiannakis et al., 1999), indicating that the dispersion of granulosa cells for culture might induce apoptosis. Moreover, the presence of

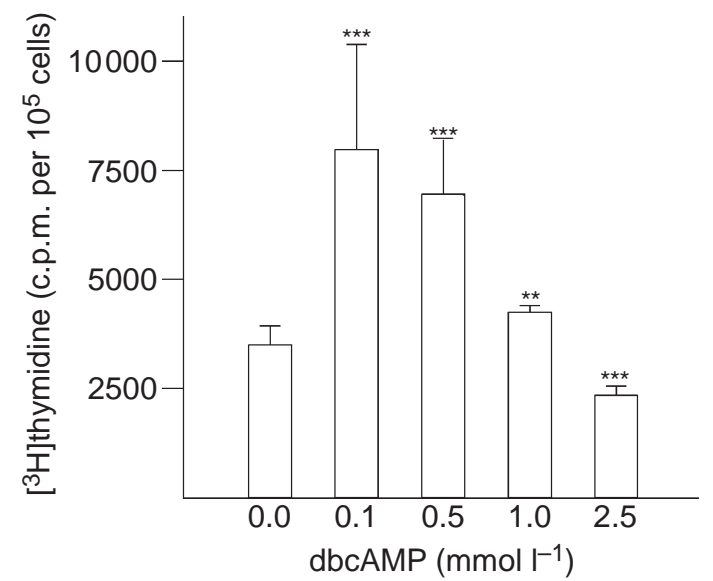

Fig. 6. Effect of increasing doses of dibutyryl cAMP (dbcAMP) on the incorporation of $\left[{ }^{3} \mathrm{H}\right]$ thymidine into DNA in rabbit granulosa cells after $72 \mathrm{~h}$ of culture in the presence of fetal calf serum (FCS). Data are mean \pm SEM of three experiments performed in triplicate. ${ }^{* *} P<0.01$ and ${ }^{* * *} P<0.001$ compared with the control value.

anti-apoptotic factors in follicular fluid resulting from interactions between granulosa and theca cells could also explain the difference in the percentage of apoptotic granulosa cells between the two culture models. The necessity of co-operation between follicular cells against apoptosis was suggested by Hsueh et al. (1996). Indeed, in rats, FSH and insulin-like growth factor I (IGF-I) inhibited apoptosis in cultured preovulatory follicles (Chun et al., 1994), but were ineffective in isolated cultured granulosa cells removed from preovulatory follicles (Tilly et al., 1992; Aharoni et al., 1995).

In our study, no anti-apoptotic effect of increasing doses of $\mathrm{FSH}$ in isolated rabbit granulosa cells was observed whatever the conditions of culture. Although FSH has been demonstrated to be a major survival factor in the ovary in vivo (Billig et al., 1994), its effect on apoptosis of isolated granulosa cells in vitro is controversial. In serum-free conditions, FSH was ineffective in isolated cultured granulosa cells removed from rat preovulatory follicles (Aharoni et al., 1995) and attenuated apoptosis in cultured pig (Guthrie et al., 1998) and bovine (Yang and Rajamahendran, 2000) granulosa cells from small and medium-sized follicles. The anti-apoptotic effect of FSH appears to depend on the differentiation status of isolated granulosa cells. In preovulatory follicles cultured in serum-containing medium, the percentage of apoptotic granulosa cells was low (about 6\%) and increasing doses of FSH or hCG did not decrease this percentage. The protective effect of FSH against apoptosis was only observed when rabbit granulosa cells were isolated after the culture of intact follicles in serum-free conditions and this effect was dose-dependent. This result was in agreement with the results of Chun et al. (1994) in rat preovulatory follicles in vitro.

As in the presence of FSH, no significant effect of hCG on apoptosis was observed in cultured isolated granulosa cells. This finding is in agreement with the results of Aharoni et al. 
(1995). In contrast, Dharmarajan et al. (1994) reported an anti-apoptotic effect of hCG on apoptosis induced by the absence of serum during $2 \mathrm{~h}$ culture of rabbit luteal cells. The different status of ovarian cells used could explain this discrepancy. In contrast to FSH, no significant antiapoptotic effect of hCG was observed in granulosa cells analysed after $72 \mathrm{~h}$ of culture of intact follicles with or without serum in the present study, whereas in intact preovulatory rat follicles, hCG suppressed apoptosis after 24 h of culture (Chun et al., 1994).

In the present study, in the presence of serum, dbcAMP stimulated phosphatidylserine exposure in isolated granulosa cells and in granulosa cells obtained from cultured preovulatory follicles in a dose-dependent way. Results obtained in isolated granulosa cells support the findings by others that high doses of CAMP analogues (used at saturating doses for steroidogenesis) stimulated apoptosis of granulosa cells from rat preovulatory follicles (Aharoni et al., 1995) and apoptosis of human granulosa cells (Makrigiannakis et al., 1999) in vitro. Moreover, in nonovarian cells, cAMP stimulates apoptosis in a rat leukaemia cell line (Duprez et al., 1993) and in thymocytes (McConkey et al., 1992).

In contrast, the effect of dbcAMP in cultured preovulatory follicles is quite different from results obtained in cultured preantral and early antral rat follicles, as 8bromo-cAMP did not suppress apoptosis in preantral follicles (McGee et al., 1997; Hsueh et al., 2000), whereas a high dose of dbcAMP inhibited apoptosis in early preantral follicles (Chun et al., 1996). These contrasting results may reflect stage-dependent hormonal regulation of apoptosis during follicular development. Firstly, as underlined by McGee et al. (1998), the in vivo observation that preantral rat follicles do not ordinarily undergo apoptosis in significant numbers indicates that survival of preantral follicles may be regulated differently from survival of antral follicles. Moreover, in rats, IGF-I, interleukin $1 \beta$ (IL-1 $\beta$ ), LH, epidermal growth factor (EGF), fibroblast growth factor (bFGF) and growth hormone $(\mathrm{GH})$ exerted a less protective effect in vitro on early antral follicles than on preovulatory follicles (Hsu and Hsueh, 1997). Another study performed in pig granulosa cells showed that FSH treatment protects granulosa cells isolated from small and medium-sized follicles from undergoing $\mathrm{GnRH}$-mediated apoptosis, but fails to have a protective effect in granulosa cells from large follicles (Takekida et al., 2000).

The results of the present study show that the lower doses of dbcAMP caused an increase in the incorporation of $\left[{ }^{3} \mathrm{H}\right]$ thymidine into DNA without detectable anti-apoptotic effects in isolated granulosa cells. This result is consistent with the fact that FSH, which caused a modest increase in intracellular cAMP concentration, had no effect on apoptosis of isolated granulosa cells.

In our experiments, the high doses of dbcAMP caused apoptosis and, at the same time, a decrease in the incorporation of $\left[{ }^{3} \mathrm{H}\right]$ thymidine in granulosa cells, whereas the percentage of propidium iodide-unlabelled granulosa cells
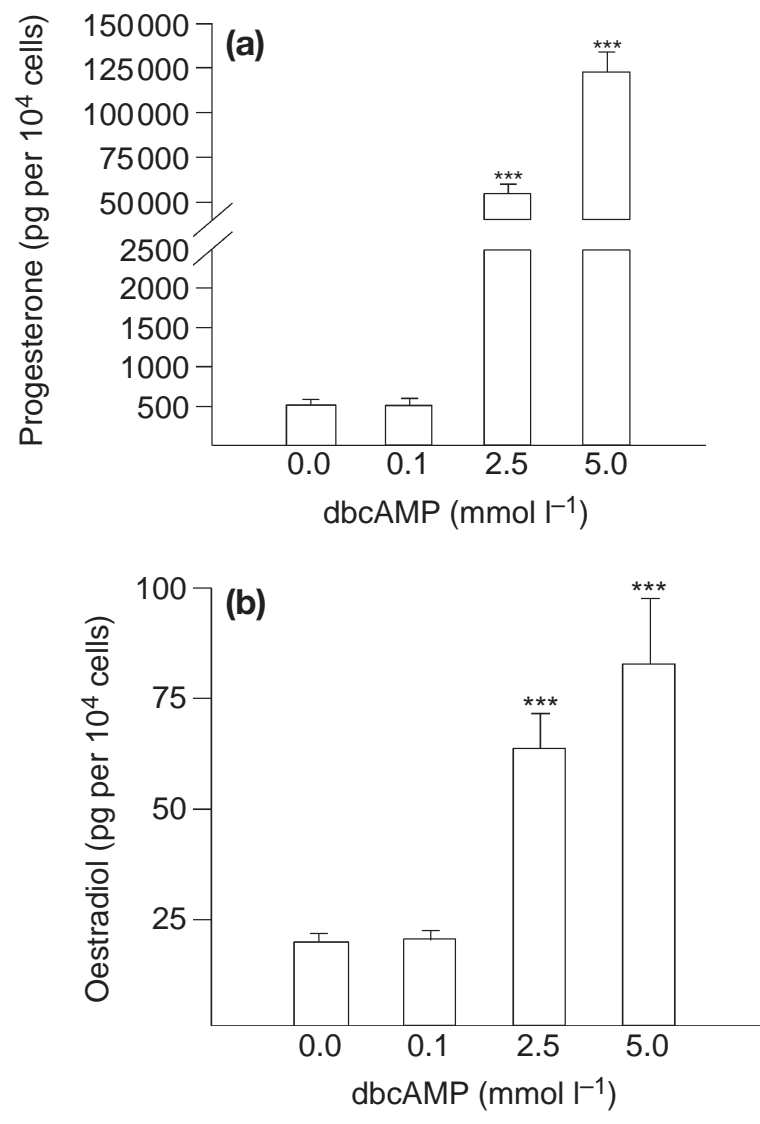

Fig. 7. Effect of increasing doses of dibutyryl cAMP (dbcAMP) on the production of (a) progesterone and (b) oestradiol in isolated rabbit granulosa cells cultured for $72 \mathrm{~h}$ with fetal calf serum (FCS). Data are mean \pm SEM of three experiments performed in duplicate. $* * * P<0.001$ compared with control value.

(cells without a damaged membrane) did not change significantly, excluding a cytotoxic effect of dbcAMP. Moreover, the same effect was observed using another cAMP analogue, 8-bromo-cAMP (data not shown). Such an effect of dbcAMP on the incorporation of $\left[{ }^{3} \mathrm{H}\right]$ thymidine has also been observed in human granulosa cells (Yong et al., 1992) and corresponded to the decrease in the mitotic index that occurs during the atretic process (Hirshfield and Midgley, 1978).

When granulosa cell apoptosis was induced by high doses of dbcAMP in the present study, an increase in oestradiol and progesterone production was also observed. This observation was also made by Aharoni et al. (1995) and may be explained by the compartmentalization of steroidogenic organelles that occurs during the first $24 \mathrm{~h}$ of cAMP induction of apoptosis. Thus, steroidogenesis would take place in apoptotic cells if the intracellular disorganization remains moderate (Aharoni et al., 1995).

The dose of 5 mmol dbcAMP I-1 was supraphysiological (but not cytotoxic as shown by the percentage of propidium iodide-unlabelled cells), as it induced a ten-fold higher stimulation of progesterone secretion than did hCG. Thus, at 
this dose, granulosa cells would be more vulnerable because of this hyperstimulation of steroidogenesis and could then become apoptotic. However, the dose of $2.5 \mathrm{mmol}$ dbcAMP $\left.\right|^{-1}$ induced the same stimulation of progesterone production in granulosa cells as did hCG and, at the same time, induced a stimulation of apoptosis, whereas hCG did not. Thus, is can be supposed that the induction of apopto-

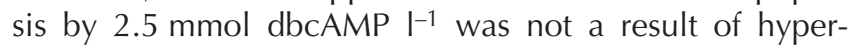
stimulation of steroidogenesis.

The physiological meaning of an apoptotic effect of high concentrations of dbcAMP remains unclear. Nevertheless, if a transitory increase in CAMP were to occur in granulosa cells in vivo, apoptosis could be prevented by rapid desensitization of the cells, as suggested by Amsterdam et al. (1996).

The mechanism by which cAMP can induce apoptosis is not yet clear and different hypotheses have been suggested. In some cell lines, over-expression of cAMP-responseelement-binding (CREB) protein results in apoptosis (Saeki et al., 1999). Thus, an increase in the intracellular cAMP content may induce apoptosis through activation of CREB. In rat granulosa cells, cAMP-induced apoptosis involved the activation of tumour suppressor gene p53 (Keren-Tal et al., 1995). cAMP appears to activate P53 via inhibition of the expression of oncoprotein Mdm2 (Hosokawa et al., 1998), which inhibits P53 activity (Wu et al., 1993). Makrigiannakis et al. (1999) suggested that cAMP-induced apoptosis in cultured human granulosa cells was mediated through downregulation of the expression of the $\mathrm{N}$ cadherins expressed in vivo and regulated during follicular maturation.

In conclusion, in the present study it was demonstrated in the same experiment that FCS reduces the occurrence of apoptosis and also influences the effects of FSH and dbcAMP on apoptosis. It was also shown that the effect of gonadotrophins on apoptosis of preovulatory rabbit follicles is different in isolated granulosa cells and in intact follicles, showing that the regulation of apoptosis in granulosa cells appears to require paracrine interactions within the follicle. In contrast, cAMP had a biphasic effect on growth and apoptosis of granulosa cells; low doses of dbcAMP can induce DNA synthesis, whereas high concentrations induce apoptosis. The physiological meaning of this latter paradoxical effect remains to be elucidated.

The authors would like to thank V. Salaun (Haematology laboratory, $\mathrm{Pr}$ Troussard, $\mathrm{CHU}$ de Caen) for her assistance in the use of the flow cytometer and the National Hormone and Pituitary Program (NIDDK, Bethesda, MD) for providing purified ovine FSH. The authors would like to thank C. Marguerite for skillful technical laboratory assistance and help in the preparation of the manuscript.

\section{References}

Aharoni D, Dantes A, Oren M and Amsterdam A (1995) cAMP-mediated signals as determinants for apoptosis in primary granulosa cells Experimental Cell Research $\mathbf{2 1 8} 271-282$
Amsterdam A, Keren-Tal I and Aharoni D (1996) Cross-talk between cAMP and $\mathrm{p} 53$-generated signals in induction of differentiation and apoptosis in steroidogenic granulosa cells Steroids $61252-256$

Benhaïm A, Féral C, Langris M, Bocquet J and Leymarie P (1995) Progesterone secretion and proliferation in cultured rabbit granulosa cells under conditions of $\beta$-D-xyloside-induced inhibition of proteoglycan synthesis Biology of Reproduction 52 939-946

Billig H, Furuta I and Hsueh AJW (1994) Gonadotropin-releasing hormone directly induces apoptotic cell death in the rat ovary: biochemical and in situ detection of deoxyribonucleic acid fragmentation in granulosa cells Endocrinology 134 245-252

Chun SY, Billig H, Tilly JL, Furuta J, Tsafriri A and Hsueh AJW (1994) Gonadotropin suppression of apoptosis in cultured preovulatory follicles: mediatory role of endogenous insulin-like growth factor I Endocrinology 135 1845-1853

Chun SY, Eisenhauer KM, Minami S, Billig H, Perlas E and Hsueh AJW (1996) Hormonal regulation of apoptosis in early antral follicles: folliclestimulating hormone as a major survival factor Endocrinology 137 1447-1456

Dharmarajan AM, Goodman SB, Tilly KI and Tilly JL (1994) Apoptosis during functional corpus luteum regression: evidence of a role for chorionic gonadotropin in promoting luteal cell survival Endocrine Journal 2 295-303

Duprez EJ, Gjersten BT, Bernard O, Lanotte M and Dosheland SO (1993) Antiapoptotic effect of heterozygously expressed mutant RI (Ala $336 \rightarrow$ Asp) subunit of cAMP kinase I in a rat leukemia cell line Journal of Biological Chemistry 268 8332-8340

Féral C, Le Gall S and Leymarie P (1995) Angiotensin II modulates steroidogenesis in granulosa and theca in the rabbit ovary: its possible involvement in atresia European Journal of Endocrinology 133 747-753

Guthrie HD, Garrett WM and Cooper BS (1998) Follicle-stimulating hormone and insulin-like growth factor- 1 attenuate apoptosis in cultured porcine granulosa cells Biology of Reproduction 58 390-396

Hirshfield AN and Midgley JAR (1978) Morphometric analysis of follicular development in the rat Biology of Reproduction 19 606-611

Hosokawa K, Aharoni D, Dantes A et al. (1998) Modulation of Mdm2 expression and p53-induced apoptosis in immortalized human ovarian granulosa cells Endocrinology 139 4688-4700

Hsu SH and Hsueh AJW (1997) Hormonal regulation of apoptosis. An ovarian perspective Trends in Endocrinology and Metabolism 8 207-213

Hsueh AJW, Eisenhauer K, Chun S-Y, Hsu S-Y and Billig H (1996) Gonadal cell apoptosis Recent Progress in Hormone Research 51 433-456

Hsueh AJW, McGee EA, Hayashi M and Hsu S-Y (2000) Hormonal regulation of early follicle development in the rat ovary Molecular and Cellular Endocrinology 163 95-100

Hu CL, Cowan RG, Harman RM, Porter DA and Quirk SM (2001) Apoptosis of bovine granulosa cells after serum withdrawal is mediated by Fas antigen (CD95) and Fas ligand Biology of Reproduction 64 518-526

Hughes FM and Gorospe WC (1991) Biochemical identification of apoptosis (programmed cell death) in granulosa cells: evidence for a potential mechanism underlying follicular atresia Endocrinology 129 2415-2422

Kaipia A, Chun SY, Eisenhauer K and Hsueh AJW (1996) Tumor necrosis factor-alpha and its second messenger, ceramide, stimulate apoptosis in cultured ovarian follicles Endocrinology 137 4864-4870

Keren-Tal I, Suh BS, Dantes A, Lindner S, Oren M and Amsterdam A (1995) Involvement of p53 expression in CAMP-mediated apoptosis in immortalized granulosa cells Experimental Cell Research 218 283-295

McConkey DJ, Jondal M and Orrenius S (1992) Cellular signaling in thymocyte apoptosis Seminars of Immunology 4 372-377

McGee E, Spears N, Minami S, Hsu SY, Chun SY, Billig H and Hsueh AJW (1997) Preantral ovarian follicles in serum-free culture: suppression of apoptosis after activation of the cyclic guanosine $3^{\prime}, 5^{\prime}$-monophosphate pathway and stimulation of growth and differentiation by folliclestimulating hormone Endocrinology 138 2417-2424

McGee E, Hsu SY, Kaipia A and Hsueh AJW (1998) Cell death and survival during ovarian follicle development Molecular and Cellular Endocrinology 140 15-18 
Makrigiannakis A, Coukos G, Christofidou-Solomidou M, Gour BJ, Radice GL, Blaschuk O and Coutifaris C (1999) N-cadherin-mediated human granulosa cell adhesion prevents apoptosis. A role in follicular atresia and luteolysis? American Journal of Pathology 154 1391-1406

Saeki K, Yuo A, Suzuki E, Yakazi Y and Takaku F (1999) Aberrant expression of cAMP-response-element-binding ('CREB') induces apoptosis Biochemical Journal 343 249-255

Takekida S, Deguchi J, Samoto T, Matsuo H and Maruo T (2000) Comparative analysis of the effects of gonadotropin-releasing hormone agonist on the proliferative activity, apoptosis, and steroidogenesis in cultured porcine granulosa cells at varying stages of follicular growth Endocrine 12 61-67

Tilly JL, Kowalski KJ, Johnson AL and Hsueh AJW (1991) Involvement of apoptosis in ovarian follicular atresia and postovulatory regression Endocrinology 129 2799-2801

Tilly JL, Billig H, Kowalski KI and Hsueh AJW (1992) Epidermal growth factor and basic fibroblast growth factor suppress the spontaneous onset of apoptosis in cultured rat ovarian granulosa cells and follicles by a tyrosine kinase-dependent mechanism Molecular Endocrinology 6 1942-1950

Vermes I, Haanen C, Steffens-Nakken H and Reutelinsperger C (1995) A novel assay for apoptosis: flow cytometric detection of phosphatidylserine expression on early apoptotic cells using fluorescein labelled annexin $V$ Journal of Immunological Methods 184 39-51

Wu X, Bayle JH, Olson D and Levine AJ (1993) The p53-mdm-2 autoregulatory feedback loop Genes and Development 7 1126-1132

Yang MY and Rajamahendran R (2000) Morphological and biochemical identification of apoptosis in small, medium, and large bovine follicles and the effects of follicle-stimulating hormone and insulin-like growth factor I on spontaneous apoptosis in cultured bovine granulosa cells Biology of Reproduction 62 1209-1217

Yong EL, Baird DT and Hillier SG (1992) Mediation of gonadotrophinstimulated growth and differentiation of human granulosa cells by adenosine-3', 5'-monophosphate: one molecule, two messages Clinical Endocrinology 37 51-58

Received 20 December 2000.

First decision 21 March 2001.

Final version received 10 October 2001 Accepted 22 October 2001. 